\title{
Building in relation
}

The concrete frame of Steven Holl's new building for Glasgow School of Art, due to be completed later this year, has now risen out of the ground. The frame looms over Charles Rennie Mackintosh's building sited directly across the street, currently waiting for the pearlescent cladding which will perhaps change the impression of its bulk. Johnny Rodger, in this issue of arq (pp. 24-36), reads the new building in relation to the old, finding themes which simultaneously tie together Mackintosh's and Holl's designs and set them apart. For Holl, building in relation to Mackintosh must be no small task. Yet all architects conceive their work in relation to others: to the other designers who inhabit their imaginations, to the chief protagonists of ideas which inspire or trouble them, to the social, economic and technical cultures which surround them. This issue illustrates how architecture can emerge from its relations.

Still in Glasgow, across the River Clyde in New Gorbals, Florian Urban examines a 'textbook example' of neo-traditional housing on a contested site previously occupied by the Gorbals tenements (1870s-1960s) and the high-rise Hutchesontown flats (1960s-1990s). He reviews how the historical tenement type has been adapted to contemporary needs while conveying a revised conception of the city's past (pp. 37-48). Westwards, in Northern Ireland, Paul Larmour shows how the architect Philip Bell pursued the 'international style' in the topography and the economic context of 'a country closely tied to tradition, its architecture dominated for much of his career by a deeply conservative taste' (pp. 49-61). Much further west, Styliane Philippou examines architecture made in the extraordinary context of pre-revolutionary Havana (pp. 73-88). Built in the 1950s for Americans to gamble and party in the shadow of the Cold War, these are projects she characterises as 'Vanity Modern'. Philippou also contributes an obituary (pp. 9-14), reviewing the extraordinary 70-year career of Oscar Niemeyer (1907-2012), an architect whose work is often imagined in relation to the project of nation-building in Brazil. Rosa Urbano Gutiérrez, meanwhile, examines Le Corbusier's idea of the mur neutralisant, a prototype of double-glass façade with an air-conditioning circuit which was intended to change a building's relationship to its climate (pp. 63-71).

Pekka Passinmäki, in his 'perspective', responds to Charles Jencks' reflections on relations (pp. 19-23). For Jencks, the scientific model of the origins of the cosmos itself provides a cosmology, a theory of the world that we find ourselves in. To him, our world is characterised by self-organising systems. He echoes Deleuze and Guattari's interest in distributed agency, in the chaotic ways that diverse people and things coalesce to effect change. Whether or not one accepts Jencks' model of the cosmos as an infinite maze of contingency, it is clear that to build is always to build in relation.

THE EDITORS 


\section{Antiquaries Journal}

Published for the Society of Antiquaries of London

\section{Editors}

Kate Owen, Society of Antiquaries of London, United Kingdom

Christopher Catling, Society of Antiquaries of London, United Kingdom

The Antiquaries Journal aims to reflect the multi-disciplinary nature of the study of material culture, publishing a balanced mix of papers from all periods, from prehistory to the recent past. The journal seeks papers that address research questions from a variety of perspectives, combining, for example, historical, art historical, architectural, linguistic, archaeological and scientific data. It will be essential reading for archaeologists, architectural and art historians and material culture specialists, as well as those involved in conservation in its broadest application.

The Journal now offers electronic access to all subscribers, with material to be published in two major releases in March and September.

\section{Price information}

is available at: http://journals.cambridge.org/ant

\section{Free email alerts}

Keep up-to-date with new material - sign up at http://journals.cambridge.org/alerts

To subscribe contact Customer Services

\section{in Cambridge:}

Phone +44 (0)1223 326070

Fax +44 (0)1223 325150

Email journals@cambridge.org

\section{in New York:}

Phone +1 (845) 3537500

Fax +1 (845) 3534141

Email

subscriptions_newyork@cambridge.org 